\title{
EDUKASI PENGGUNAAN MONOFILAMENT DALAM DETEKSI DINI NEUROPATI SENSORI DIABETES MELLITUS TIPE 2 PADA KADER DI TENGAH PANDEMI COVID-19 KELURAHAN KOLO KOTA BIMA
}

\author{
A. Haris ${ }^{1}$, Julhana ${ }^{2}$ \\ Poltekes Kemenkes Mataram \\ Email Korespondensi: julhana27@gmail.com \\ Disubmit: 19 Oktober 2021 Diterima: 4 Desember $2021 \quad$ Diterbitkan: 02 Januari 2022 \\ DOI: https://doi.org/10.33024/jkpm.v1i1.5346
}

\begin{abstract}
ABSTRAK
Neuropati atau sering disebut sebagai gangguan sensasi merupakan salah satu komplikasi yang sering ditemukan pada pasien diabetes Mellitus tipe 2. Kejadian neuropati sering tidak disadari oleh pasien sehingga mengakibatkan munculnya Diabetic Foot Ulcer. Deteksi dini neuropati diabetic sangat penting pada pasien dengan DM karena pencegahan bisa menurunkan morbiditas dan mortalitas.. Metode yang dilakukan meliputi tahap persiapan, tahap pelaksanaan, monitoring dan evaluasi. strategi pelaksanaan dengan melakukan pre test sebelum kegiatan dilaksanakan, kemudian membagikan modul dan video penggunaan alat pengecekan gula darahdan penggunaan monofilament test, setelah itu di evaluasi dengan post test. Hasil yang didapatkan $90 \%$ kader yang hadir mememahami dan bisa mempraktekan cara pengecekan gula darah secara mandiri dan menggunkan monofilament tes. Sedangkan kegaiatan dengan 50 penyandang diabetes $40 \%$ mengalami gangguan neuropati sensori, maka dapat disimpulakan adanya peningkatan pengetahuan dan keterampilan para kader tentang deteksi dini neuropati pada pasien diabetes mellitus tipe 2 yang meliputi, pengertian DM, tanda dan gejala, penatalaksanaan, komplikasi, tanda gangguan neuropati dan cara mendeteksinya, ditandai dengan kemampuan kader dan penyandang diabetes mampu menjawab dan mempraktikan pertanyaan dari pengabdi.
\end{abstract}

Kata Kunci: Edukasi, Pelatihan, Monofilament tes, Neuropati.

\section{ABSTRACT}

Neuropathy or often referred to as impaired sensation is one of the complications that are often found in patients with type 2 diabetes mellitus. Early detection of diabetic neuropathy is very important in patients with DM because prevention can reduce morbidity and mortality. The methods used include the preparation stage, implementation stage, monitoring and evaluation. the implementation strategy was to do a pre test before the activity was carried out, then distribute modules and videos on the use of blood sugar checking tools and the use of monofilament tests, after which they were evaluated with a post test. The results obtained were $90 \%$ of the cadres who attended understood and could practice how to independently check blood sugar and use the monofilament test. While activities with 50 people with diabetes $40 \%$ experiencing sensory neuropathy disorders, it can 
be concluded that there is an increase in knowledge and skills of cadres about early detection of neuropathy in patients with type 2 diabetes mellitus which includes understanding of DM, signs and symptoms, management, complications, signs of neuropathic disorders. and how to detect it, is marked by the ability of cadres and people with diabetes to be able to answer and practice questions from the servants.

Keywords: Education, Training, Monofilament test, Neuropathy

\section{PENDAHULUAN}

Diabetes mellitus merupakan penyakit kronis progresif yang ditandai dengan ketidakmampuan tubuh utuk melakukan metabolisme karbonhidrat, lemak dan protein, mengarah ke hiperglikemia (kadar glukosa darah tinggi) (Fain.J.A, 2014). Berdasarkan data dari International Diabetes Federation (IDF,2014), jumlah penyandang diabetes mellitus diseluruh dunia sebanyak 366 juta jiwa di tahun 2011, meningkat menjadi 387 juta jiwa di tahun 2013, sedangkan pada tahun 2017 Indonesia menduduki urutan ke 6 dibawah Mexico dengan jumlah 10,3 juta yang terdiagnosis (8,9-11,1\%). Pravalensi Diabetes mellitus di Indonesia adalah 1,5\%, tertinggi terjadi di Daerah Istimewa Yogyakarta sebanyak 2,6\%, sedangkan untuk propinsi Nusa Tenggara Barat sebanyak 0,9\% setara dengan Sumatra Selatan dan Bengkulu, sedangkan yang paling rendah di propinsi Lampung sebanyak 0,7\%.

Pravalensi diabetes mellitus yang tertinggi di Provinsi Nusa Tenggara Barat terdapat pada Kota Mataram sebanyak 1,7\%, Kota Bima 1,4\%, sedangkan Kabupaten Bima merupakan urutan ke 3 tertinggi yaitu sebanyak 1,0\% (Badan Penelitian dan Pengembangan Kesehatan, 2013). Berdasarkan data riskesdas tahun 2018 di NTB diperoleh 36.486 orang penderita diabetes. Di Kota Bima terdapat 2.847 penderita diabetes mellitus (Dinas Kesehatan, 2017).

Tingginya angka penyakit diabetes mellitus di Kota Bima menjadi salah satu perhatian dalam melaksanakan pengabdian kepada masayarakat di Kota Bima. Kecamatan asakota merupakan wilayah yang paling luas di Kota Bima dengan luas $69,03 \mathrm{~km}^{2}$ dan merupakan wilayah yang dekat dengan pesisir pantai serta merupakan wilayah pinggiran yang memiliki banyak masalah kesehatan salah satunya di kelurahan kolo. Masalah kesehatan yang paling banyak ditemui adalah PHBS, diare, hipertensi dan diabetes mellitus. Meskipun telah dibangun pusat pelayanan kesehatan, masyarakat dengan penyakit diabetes mellitus jarang memeriksakan diri untuk melakukan pemeriksaan kadar gula darah serta kurangnya pengetahuan akan tanda dan gejala dari penyakit tersebut. Hal ini dikarenakan rata-rata masyarakat kelurahan kolo memiliki pekerjaan sebagai nelayan sehingga penyakit tidak ditangani secara tepat dan cepat dan masyarakat mengalami gangguan neuropati sensori sebagai akibat dari penyakit diabetes mellitus. Neuropati atau sering disebut sebagai gangguan sensasi merupakan salah satu komplikasi yang sering ditemukan pada pasien diabetes mellitus tipe 2 . Kejadian neuropati sering tidak disadari oleh pasien sehingga mengakibatkan munculnya Diabetic Foot Ulcer (DFU) .

Dalam penelitian yang dilakukan Hapipah, 2016 deteksi dini neuropati diabetic sangat penting pada pasien dengan DM karena pencegahan bisa menurunkan morbiditas dan mortalitas. Pemeriksaan kaki untuk deteksi dini adanya gangguan neuropati sensori dapat dilakukan melalui beberapa cara yaitu tes monofilamen 10 gr. Pemeriksaan neurosensori kaki diabetik dengan tes monofilamen $10 \mathrm{gr}$ 
merupakan salah satu metode yang telah menjadi standar pemeriksaan neurosensori kaki dan efektif untuk mengidentifikasi loss of protective sensation. Namun pelaksanaannya memerlukan pelatihan, biaya dan keakurasian pemeriksaan (Hapipah, 2016).

Sehubungan dengan hal tersebut kami tertarik untuk melakukan kegiatan pengabdian kepada masyarakat sekaligus melaksanakan kegiatan pengabmas berbasis penelitian tentang "Edukasi Penggunaan Monofilament Dalam Deteksi Dini Neuropati Sensori Diabetes Mellitus Tipe 2 Pada Kader Ditengah Pandemi Covid-19". Dengan adanya kegiatan tersebut diharapkan menjadi solusi permasalahan dalam meningkatkan pengetahuan dan keterampilan kader dalam mendeteksi dini terjadinya neuropati sensori pada pasien diabetes mellitus tipe 2 di tengah pandemic covid-19. Salah satu tujuan dari edukasi adalah meningkatkan pengetahuan yang akan menyebabkan terjadinya perubahan sikap dan gaya hidup, meningkatkan kepatuhan yang mempengaruhi kualitas hidup (Oktorina, Sitorus, \& Sukmarini, 2019)

Solusi yang dilakukan melalui pre test pada Kader Kesehatan yang berada di Kelurahan Kolo Kota Bima tentang penyakit diabetes mellitus tipe 2 serta gangguan neuropati. Didapatkan hasil bahwa 10\% memiliki pengetahuan yang cukup, sedangkan $90 \%$ memiliki pengetahuan yang kurang.

1. Kuesioner pre test: dilaksanakan sebelum kegiatan dimulai, yang diisi oleh 10 kader yang hadir. Terdiri dari 20 soal dengan pilihan benar salah. Hasil dari pre test ini bermasfaat untuk mengetahui sejauh mana pemahaman kader kesehatan tentang penyakit diabetes mellitus tie 2,ganggguan neuropati dan cara mendeteksi dini gangguan neuropati.

2. Edukasi dan pelatihan: materi yang diberikan dalam penyuluhan ini meliputi tentang penyakit diabetes mellitus tipe 2 , komplikasi, gangguan neuropati dan mendeteksi dini gaggguan neuropati dengan menggunakan alat monofilament $10 \mathrm{~g}$. Materi yang diberikan bersumber dari buku dan jurnal terkait. Modul dan video juga dibagikan guna memudahkan kader mengerti dan memahami materi tersebut.

3. Kosioner post test: diberikan pada kegiatan berakhir.

Tujuan dari pengabdian kepada masyarakat ini yaitu Meningkatkan pengetahuan dan keterampilan kader dan masyarakat tentang diabetes mellitus dan pencegahan tentang neuropati sensori, prediksi neuropati sensori, serta mampu melakukan pemeriksaan meliputi: pemeriksaan mandiri glukosa darah dan menggunakan monofilament test dan mampu melakukan edukasi kesehatan pada kelompok berisiko/masyarakat.

\section{MASALAH}

Di Kota Bima terdapat 2.847 penderita diabetes mellitus dan merupakan urutan kedua setelah Kota Mataram dengan penderita diabetes mellitus sebanyak 1,4\% (Profil Kesehatan Provinsi NTB, 2018). Dengan tingginya angka penyakit diabetes mellitus di Kota Bima menjadi salah satu perhatian dalam melaksanakan pengabdian kepada masyarakat di Kota Bima. Kecamatan Asakota merupakan wilayah yang paling luas di Kota Bima dengan luas $69,03 \mathrm{~km}^{2}$ dan merupakan wilayah yang dekat dengan pesisir pantai serta merupakan wilayah pinggiran yang memiliki banyak masalah kesehatan salah satunya di kelurahan kolo. Masalah kesehatan yang paling 
banyak ditemui adalah PHBS, diare, hipertensi dan diabetes mellitus. Meskipun telah dibangun pusat pelayanan kesehatan, masyarakat yang memiliki penyakit diabetes mellitus jarang untuk memeriksakan diri sekedar untuk melakukan cek laboraturium pemeriksaan kadar gula darahnya. Hal ini dikarenakan rata-rata masyarakat kelurahan kolo memiliki pekerjaan sebagai nelayan sehingga penyakit tidak ditangani secara tepat dan cepat dan masyarakat mengalami gangguan neuropati sensori sebagai akibat dari penyakit diabetes mellitus.

Adapun upaya-upaya yang dilakukan dalam meningkatkan pengetahuan, keterampilan, serta upaya menurunkan angka penyakit diabetes mellitus antara lain melakukan pelatihan pada kader dalam penggunaan monofilament dalam deteksi dini neuropati sensori pada diabetes mellitus dengan cara tes monofilamen $10 \mathrm{gr}$ yang sebelumnya pernah dilakukan juga oleh Raymen (Rayman et al., 2011), melakukan health education tentang penyakit diabetes mellitus, dan peningkatan sumber daya manusia kesehatan/ petugas kesehatan tentang pentingnya deteksi dini neuropati diabetic. Partisipasi/ Proaktif masyarakat sangat diperlukan pada program kemiteraan masyarakat sehingga masyarakat menyadari bahwa penyakit diabetes dapat berakibat buruk bagi kesehatan serta memiliki komplikasi yang serius.

Pelaksanaan kegiatan pengabdian kepada masyarakat dilakukan pada kader kesehatan di Kelurahan Kolo Kota Bima sebagai implementasi dari Tri Dharma Perguruan Tinggi yang dilakukan oleh kami dosen Poltekkes Kemenkes Mataram, metode yang digunakan untuk memecahkan permasalahan tersebut adalah dengan cara memberikan edukasi dan pelatihan kepada kader kesehatan setempat. Secara rinci terkat dengan masalah,solusi, pendekatan dan kegiatan yang direncanakan tertera di table dibawah ini.

Table1. masalah, solusi, pedekatan dan kegiatan

\begin{tabular}{|c|c|c|c|}
\hline Masalah & Solusi & Pendekatan & Kegiatan \\
\hline $\begin{array}{l}\text { Rendahnya } \\
\text { pegetahuan } \\
\text { kader } \\
\text { megenai } \\
\text { penyakit } \\
\text { diabetes } \\
\text { mellitus tipe } 2\end{array}$ & $\begin{array}{ll}\text { - } & \text { Identifikasi } \\
\text { pengetahuan } \\
\text { awal kader } \\
\text { - } \quad \text { Memberi } \\
\text { edukasi }\end{array}$ & 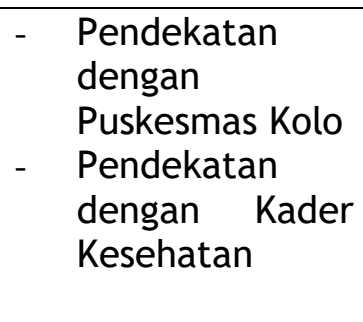 & $\begin{array}{ll}\text { - } & \text { Memberikan } \\
& \text { pre test } \\
\text { - } & \text { Memberikan } \\
\text { post test }\end{array}$ \\
\hline $\begin{array}{l}\text { Banyaknya } \\
\text { penyandang } \\
\text { diabetes } \\
\text { mellitus tipe } 2 \\
\text { yang tidak } \\
\text { menyadari } \\
\text { terjadi } \\
\text { komplikasi } \\
\text { seperti } \\
\text { gangguan } \\
\text { neuropati } \\
\text { sensori }\end{array}$ & $\begin{array}{l}\text { Memberikan } \\
\text { edukasi } \\
\text { terkait } \\
\text { komplikasi }\end{array}$ & $\begin{array}{l}\text { Pendekatan } \\
\text { dengan anggota } \\
\text { prolanis atau } \\
\text { penyandang DM }\end{array}$ & $\begin{array}{ll}\text { - } & \text { Membagikan } \\
\text { modul }\end{array}$ \\
\hline
\end{tabular}




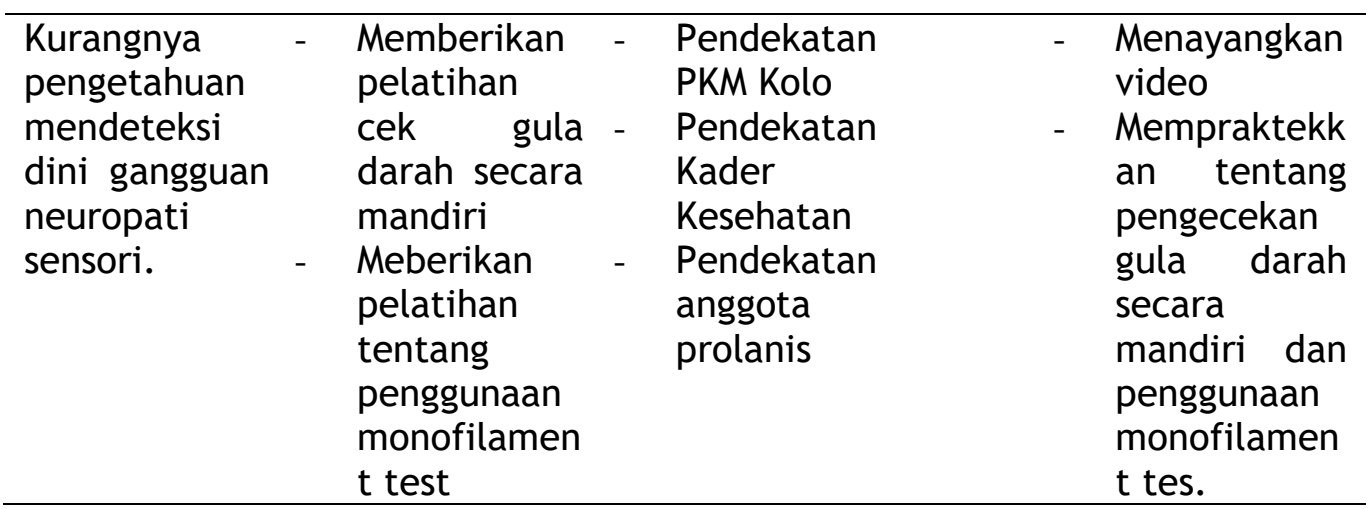

Kegiatan pengabdian kepada masyarakat dilaksanakan di Kelurahan KoloKota Bima NTB yang diawali dengan seminar proposal PKM pada bulan Desember 2020, kemudian dinyatakan lolos seleksi dan melakukan survey lokasi pada tanggal 24 Februari 2021.

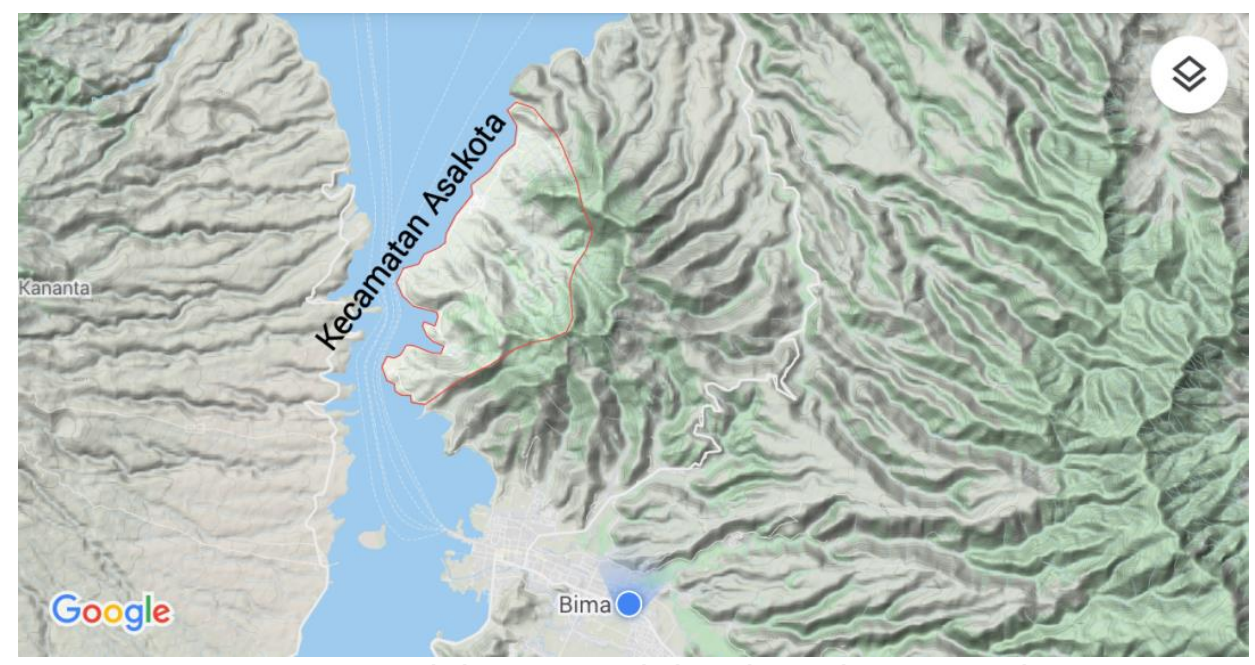

Peta lokasi pengabdian kepada masyarakat

\section{METODE}

1. Jumlah responden

Dalam kegiatan pengabdian masyarakat ini diberikan kepada 10 kader kesehatan dan kemudian 10 kader kesehatan tersebut mengaplikaskan kepada 50 masyarakat/responden.

2. Pelaksanaan kegiatan

\section{Persiapan}

a. Menyediakan monofilament $10 \mathrm{gr}$

b. Menyediakan alat cek gula darah dan bahan habis pakai

c. Menyediakan modul dan video

d. Menyediakan LCD

e. Menyediakan sound system

f. Membagi tugas dengan mahasiswa

g. Melatih mahasiswa penggunaan monofilament 
h. Menyiapkan SAP

i. Menyediakan masker

j. Menyediakan tempat cuci tangan

\section{Pelaksanaan}

a. Melakukan survey tempat lokasi kegiatan

b. Permohonan ijin pelaksanaan kegiatan pada lahan

c. Permohonan ijin pelaksanaan kegiatan pada Kepala Puskesmas

d. Melakukan kontrak waktu dengan lahan

e. Melakukan kontrak waktu dengan kader setempat dan masyarakat

f. Membagikan Modul

\section{Monitoring dan Evaluasi}

a. Mengisi daftar kehadiran, peserta hadir semua sebanyak 10 kader

b. Kegiatan dilaksanakan jam 09.00-11.00 WITA

c. Melakukan pre test terhadap peserta

d. Membagikan modul

e. Memberikan edukasi dan pelatihan

f. Menayangkan vidio

g. Melakukan diskusi serta Tanya jawab

h. Melakukan praktek penggunaan monofilament $10 \mathrm{gr}$ dan pemeriksaan kaki

i. Melakukan praktek penggunaan alat cek gula darah

j. Mendemonstrasikan yang telah dipraktekkan secara mandiri

k. Memberikan pertanyaan pada peserta

l. Memberikan praktek langsung oleh kader terhadap masyarakat

m. Post test

\section{HASIL DAN PEMBAHASAN}

Edukasi dan pelatihan diberikan kepada 10 kader di kelurahan Kolo Kecamatan Asakota Kota Bima berjalan dengan lancar, ditandai dengan adanya interaksi yang aktif antara pengabdi dan kader kesehatan setempat. Hasil pre test didapatkan $10 \%$ memiliki pengetahuan yang cukup dan $90 \%$ memiliki pengetahuan yang kurang tentang penyakit diabetes mellitus tipe 2 serta gangguan pada neuropati. Setalah diberikan edukasi dan pelatihan seluruh kader yang hadir (90\%) memahami dan mengerti cara deteksi gangguan neuropati sensori yang diakibatkan oleh penyakit diabetes. Video yang ditangyangkan juga sangat menbantu para kader untuk memahami dan mengerti langkah-langkah menggunakan alat Monofilament $10 \mathrm{~g}$.

Setelah para kader memahami tindakan menggunakan alat monofilament test, kemudian mengaplikasikan kepada 50 masyarakat yang di undang dari anggota Prolanis Puskesmas Kolo yang artinya 50 masyarakat yang hadir merupakan penyandang penyakit diabetes mellitus tipe 2. Dari 50 penyandang diabetes yang hadir ada 40\% (20 peserta) yang mengalami gangguan pada neuropati sensori, sedangkan 60\% (30 peserta) masih dalam kategori aman.

Bersarkan hasil penelitian dari Liang, Monofilamen $10 \mathrm{~g}$ menjadi salah satu alat klinis yang sangat berguna dan praktik untuk mendeteksi neuropati berat 
maupun ringan (Liang S. Tan, 2010). Hal ini sejalan dilakukan oleh (Sanklapur, Shruthi, \& Attar, 2020) yang menyatakan monofilament dapat digunakan sebagai perangkat sederhana, murah, mudah digunakan untuk mendeteksi gangguan neuropaty perifer. Neuropaty perifer diabetic (DPN) dapat menyebabkan ulkus kaki sehingga dilakukan tindakan amputasi Non- traumatic, yang merupakan penyebab morbiditas dan disabalitas di Indonesia (Ammaiyappan \& Rangarajan, 2020).

Berikut Gambar Pelaksanaan Kegiatan:
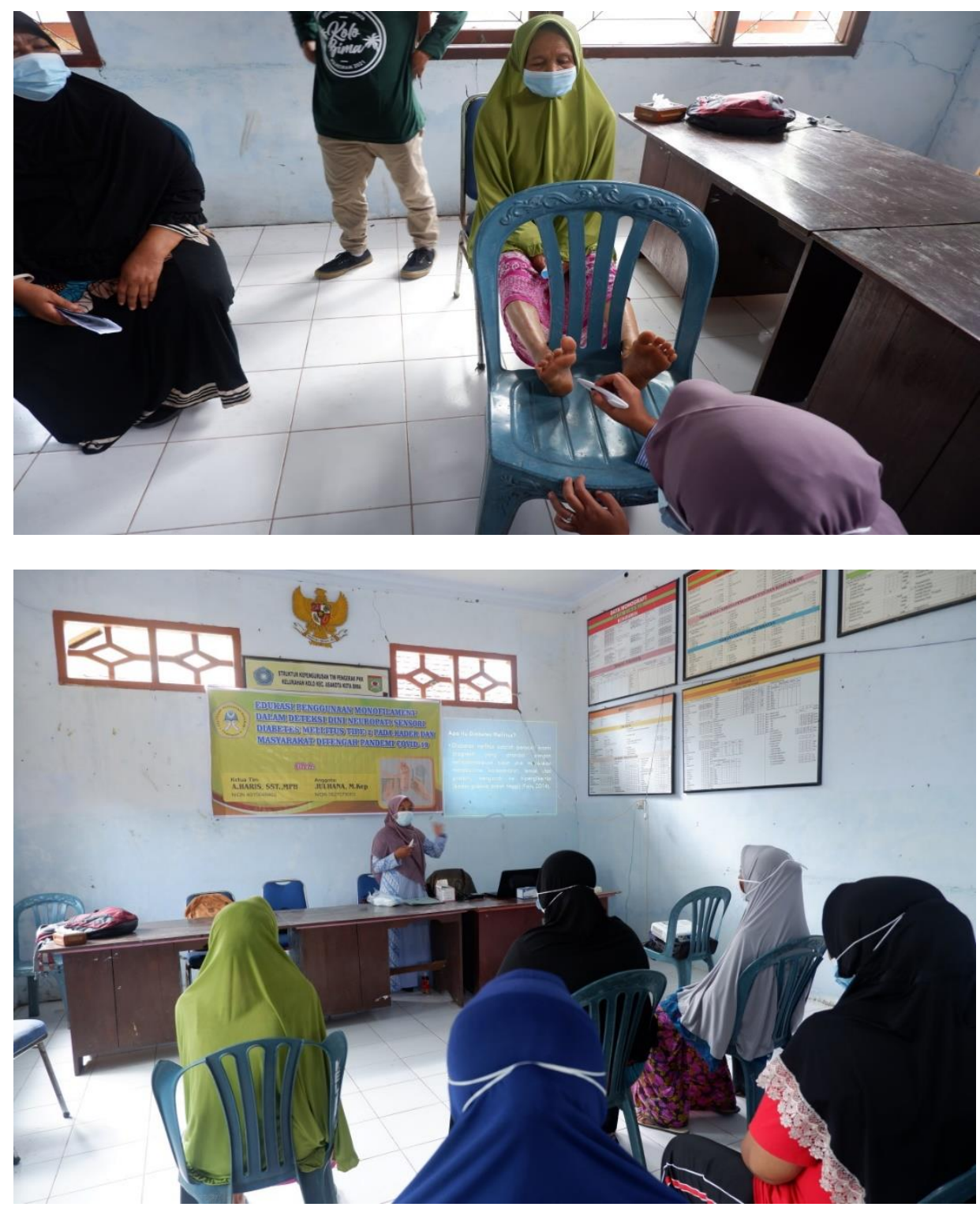


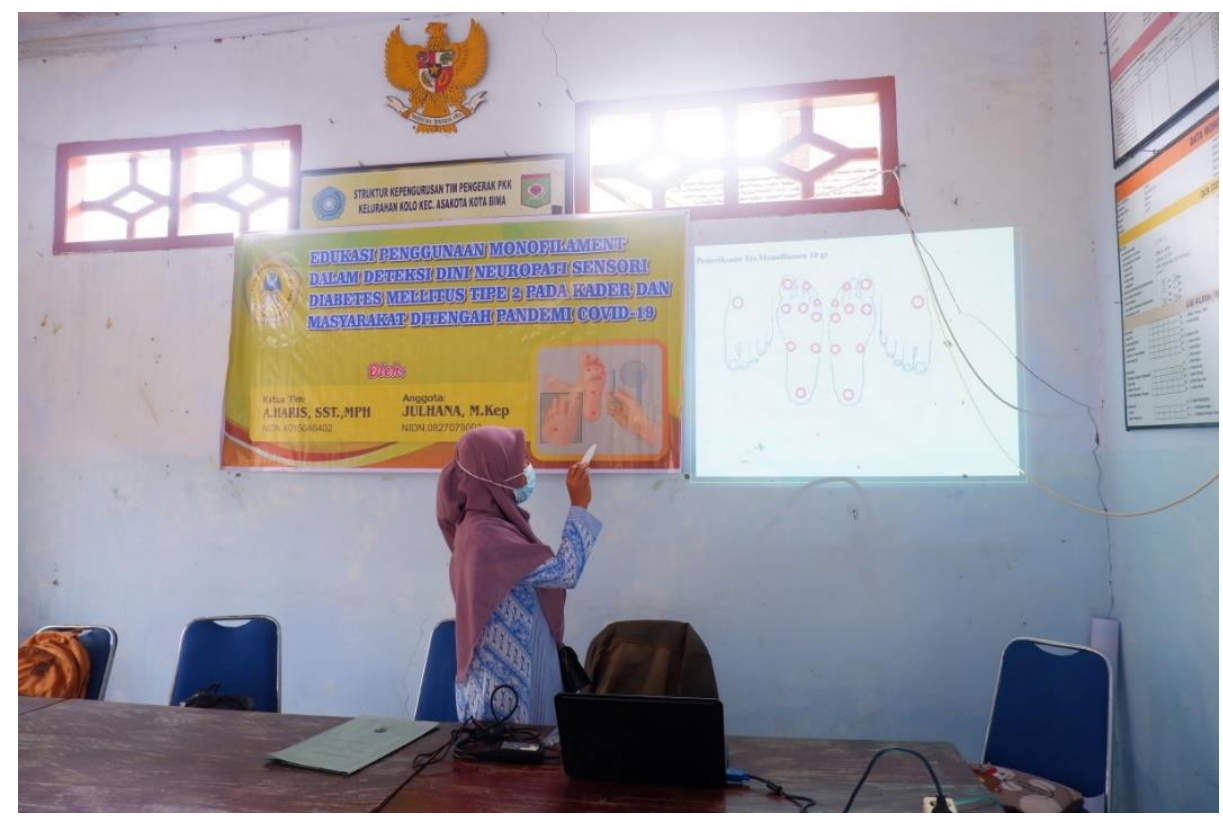

\section{KESIMPULAN}

Dari hasil kegiatan pengabdian kepada masyarakat tentang Edukasi Penggunaan Monofilament Dalam Deteksi Dini Neuropati Sensori Diabetes Mellitus Tipe 2 Pada Kader Ditengah Pandemi Covid-19 di Kelurahan Kolo Kecamatan AsaKota Kota Bima, maka dapat disimpulakan adanya peningkatan pengetahuan dan keterampilan para kader tentang deteksi dini neuropati pada pasien diabetes mellitus tipe 2 yang meliputi, pengertian DM, tanda dan gejala, penatalaksanaan, komplikasi, tanda gangguan neuropati dan cara mendeteksinya, ditandai dengan nilai pre test hanya $10 \%$ yang memiliki pengetahuan cukup, setelah diberikan penyuluhan dan pelatihan meningkat menjadi $90 \%$.

\section{DAFTAR PUSTAKA}

Ammaiyappan, S., \& Rangarajan, B. (2020). The Semmes -Weinstein monofilament examination as a single effective screening tool in the evaluation of diabetic peripheral neuropathy when compared to vibration perception threshold. National Journal of Physiology, Pharmacy and Pharmacology, 10(0), 1. https: / / doi.org/10.5455/njppp.2020.10.03076202028032020

Apriyadi, A., \& Zainaro, M. A. (2021). Pemberian Terapi Senam Kaki Pada Pasien Diabetes Mellitus Di Desa Gunung Labuhan Sungkai Selatan Lampung Utara. JURNAL KREATIVITAS PENGABDIAN KEPADA MASYARAKAT (PKM), 4(5), 12661271.

Badan Penelitian dan Pengembangan Kesehatan. (2013). Riset Kesehatan Dasar. 306.

Dinas Kesehatan. (2017). Profil Kesehatan Provinsi Nusa Tenggara Barat Tahun 2017. Provinsi Nusa Tenggara Barat Tahun 2017, 1-85.

Fain. J. A. (2014). Keperawatan Medical Bedah,Manajemen Klinis Hasil yang 
diharapkan (8 ed.). Singapore: Sauders Elsevier.

Hapipah. (2016). Efektifitas Ipswich Touch Test (IpTT) Terhadap Pemeriksaan Neuropati Sensosori Pada Pasien Diabetes Mellitus.

Liang S. Tan. (2010). The clinical use of the $10 \mathrm{~g}$ monofilament and its limitations: A review. Singapore Footcare Centre, National Healthcare Group, 6 Commonwealth Lane, GMTI Building, Level 2, Unit 01/02, Singapore 149547, Singapore. Diambil dari https://doi.org/10.1016/j.diabres.2010.06.021

Oktorina, R., Sitorus, R., \& Sukmarini, L. (2019). Pengaruh Edukasi Kesehatan dengan Self Instructional Module Terhadap Pengetahuan Tentang Diabetes Melitus. Jurnal Endurance, 4(1), 171. https://doi.org/10.22216/jen.v4i1.2995

Rayman, G., Vas, P. R., Baker, N., Taylor, C. G., Gooday, C., Alder, A. I., \& Donohoe, M. (2011). The ipswich touch test: A simple and novel method to identify inpatients with diabetes at risk of foot ulceration. Diabetes Care, 34(7), 1517-1518. https://doi.org/10.2337/dc11-0156

Sanklapur, V., Shruthi, S., \& Attar, N. (2020). Accuracy of Monofilament in the Assessment of Diabetic Neuropathy. Asian Journal of Medicine and Health, 18(august 2019), 9-15. https://doi.org/10.9734/ajmah/2020/v18i730219

Zainaro, M. A., \& Suwares, F. M. (2021). Edukasi Masyarakat Tentang Covid-19 Di Kelurahan Negeri Jaya Kecamatan Negeri Besar Kabupaten Way Kanan. JURNAL KREATIVITAS PENGABDIAN KEPADA MASYARAKAT (PKM), 4(6), 15141518.1

Zainaro, M. A., Andoko, A., \& Rahmawati, R. P. (2021). Hubungan Pengetahuan dan Sikap Terhadap Kejadian Covid-19 pada Masyarakat di Kelurahan Mulyojati Kota Metro. Malahayati Nursing Journal, 3(4), 517-528. 